\title{
CB1 and CB2 Receptor Expression and Promoter Methylation in Patients with Cannabis Dependence
}

\author{
Andrea Rotter Kristina Bayerlein Max Hansbauer Judith Weiland \\ Wolfgang Sperling Johannes Kornhuber Teresa Biermann \\ Department of Psychiatry and Psychotherapy, Friedrich-Alexander-University Erlangen-Nuremberg, \\ Erlangen, Germany
}

\section{Key Words}

CB1 and CB2 receptors - mRNA - Promoter methylation -

Tetrahydrocannabinol $\cdot$ Cannabis dependence $\cdot$

Naturalistic study

\section{Abstract}

$C B 1$ and $C B 2$ receptors are influenced via exogenous and endogenous cannabinoids. To date, little is known regarding changes in receptor expression and methylation in THC (tetrahydrocannabinol) dependence. Therefore, the $\mathrm{CB} 1$ and $C B 2$ receptor mRNA expression levels and promoter methylation status in the peripheral blood cells of 77 subjects ( 36 with THC dependence, 21 cigarette smokers and 20 nonsmokers) were assessed by quantitative real-time PCR and methylation-specific PCR. There was a significant difference in $C B 1$ receptor expression levels between the three groups (ANOVA, $\mathrm{p}<0.001$, d.f. $=2, \mathrm{~F}=71.3$ ). The mean promoter methylation (\%) was significantly negatively correlated with CB1 receptor mRNA expression levels (Spearman's rho: $r=$ $-0.37 ; p=0.002$ ). Using a mixed general linear model, it was demonstrated that the CB1 mRNA expression (as the dependent variable) was associated with the satisfaction with life scale (SWLS) $(r=0.101 ; T=2.8 ; p=0.007)$, craving (as mea- sured with the VAS; $r=-0.023 ; T=-2.3 ; p=0.023$ ) and the WHO-Assist Subscale for Cannabis consumption ( $r=-0.068$; $T=-2.4 ; p=0.02)$. CB1 receptor expression levels and methylation status appear to be altered in subjects with THC dependence.

Copyright $\odot 2012$ S. Karger AG, Basel

\section{Introduction}

Cannabis sativa continues to be the most commonly used illicit drug worldwide $[1,2]$. Since the 1990s, the rates of cannabis abuse and dependence have risen considerably [3]. The psychoactive component of cannabis is delta-(9)-tetrahydrocannabinol (delta-9-THC). THC ingested orally takes $1-3 \mathrm{~h}$ to have an effect; however, if inhaled, THC reaches the brain tissue within minutes. Users typically feel lightheaded, calm and drowsy and have a subjectively sharpened sense of humor and an increased appetite [4]. A high comorbidity with mood and anxiety disorders has been described [5]. In addition, considerable gender differences in cannabis use patterns have been described. Men predominantly consume excessive amounts within social contexts to achieve the cannabi-

\section{KARGER}

Fax +4161306 1234

E-Mail karger@karger.ch

www.karger.com
(C) 2012 S. Karger AG, Basel

1022-6877/13/0191-0013\$38.00/0

Accessible online at:

www.karger.com/ear
PD Dr. Med. Teresa Biermann

Department of Psychiatry and Psychotherapy

University Hospital Erlangen, Schwabachanlage 6

DE-91054 Erlangen (Germany)

Tel. +49 9131854 4773, E-Mail teresa.biermann@uk-erlangen.de 
noid psychoactive effects, whereas women tend to use cannabis to avoid withdrawal symptoms and alleviate mental symptoms such as anxiety or sleep problems [2].

A large body of research on cannabis has been instigated in recent years by the discovery of specific cannabinoid receptors and endogenous cannabinoids that act as ligands for these receptors, thereby influencing numerous human bodily functions [6].

THC is delivered in a sticky resin that is not water soluble. THC is usually smoked, and doses can be titrated by the frequency and depth of inhalation; however, THC can also be taken orally in fat-containing media, but absorption may vary markedly [6]. THC first and foremost activates the endocannabinoid receptors $\mathrm{CB} 1$ and partly $\mathrm{CB} 2$ and thereby mimics the effects of endocannabinoids [7]. The CB1 receptor is dominantly expressed in the central nervous system, whereas $\mathrm{CB} 2$ receptors are expressed solely in peripheral tissues and interact mainly with the immune system [8]. Both cannabinoid receptors are members of the G-protein couple class, and their activation depends on the inhibition of adenylate cyclase activity [9].

In humans, the CB1 receptors are densely expressed in the frontal regions of the cerebral cortex, in the basal ganglia and in the cerebellum; within limbic regions, the CB1 receptors are mainly found in the hypothalamus and in the anterior cingulate cortex, thus accounting for their psychoactive and locomotor effects [6]. The presynaptic localisation of $\mathrm{CB} 1$ receptors suggests an influence of cannabinoids on neurotransmitter release from axon terminals; these neurotransmitters include glutamate, GABA, noradrenaline, dopamine, serotonin and acetylcholine [6]. Exogenously delivered cannabinoids are able to induce long-lasting activation of the $\mathrm{CB} 1$ receptors in all brain regions and thereby generate a persistent inhibition of neurotransmitter release from the nerve terminals that express CB1 receptors [6]. This inhibition might explain the relaxing and, in the long run, depressive effects on the psyches of cannabis users [10,11].

The development of cannabis dependence upon cannabis misuse or consumption appears to be caused by many different genes so that the effect of each gene individually appears to be rather moderate $[12,13]$. The administration of exogenous cannabinoids influences the expression of a variety of genes and might thereby contribute to the elevated comorbidity of cannabis misuse with several psychiatric disorders such as schizophrenia or depression [4]. In general, the repeated exposure to a variety of drugs and alcohol is capable of changing gene expression patterns via epigenetic mechanisms such as
DNA methylation, histone modifications and chromatin restructuring $[14,15]$. Some studies have examined the effects of THC on gene expression patterns within the central nervous system [16]. These changes affect the cell nucleus and reach beyond a simple influence on receptors on the cell surface and membrane [17].

To date, it is unknown whether THC has an influence on the regulation of epigenetic phenomena such as histone modulation or DNA methylation [17] as is known for cigarette smoking, which is capable of influencing epigenetic phenomena in various ways [18].

Therefore, the aim of the present pilot study was to investigate the possibility of detecting changes in $\mathrm{CB} 1$ and CB2 mRNA expression levels and promoter methylation statuses using a digestion-based PCR assay in peripheral blood lymphocytes comparing THC-dependent subjects with a sex- and age-matched control group comprising cigarette smokers and nonsmokers in relation to several clinical variables as sex, age, body mass index (BMI), cravings, abuse of several other substances and satisfaction with life.

\section{Subjects and Methods}

\section{Patients and Design}

The present study was approved by the Ethics Committee of the University of Erlangen-Nuremberg. In total, 77 subjects were recruited for this study on a voluntary basis. Of these subjects, 36 suffered from THC dependence. The study group comprised 20 age- and sex-matched otherwise mentally and physically healthy cigarette smokers and 21 nonsmokers and never-smokers. The voluntary participants were interviewed once. The questionnaires were administered to all subjects in the following order: the demographic data were assessed, a psychiatric symptom checklist was applied to rule out comorbid psychiatric diseases, the satisfaction with life scale (SWLS) was evaluated, the cannabis craving was evaluated using a visual analogue scale, the Fagerström Test for nicotine dependence was assessed and finally the WHO Assist was measured.

The 36 THC-dependent subjects had an established diagnosis of THC dependence according to DSM-IV and ICD-10 and signed an informed consent form before participating in any part of the study. Most of these subjects chose to use a pseudonym so that data protection was ensured; the data of those who did not stay anonymous were processed according to the Laws of Data Protection of German Law. All THC-dependent subjects remained under the influence of THC consumption during the study according to their anamnestic data.

CB1 and CB2 mRNA expression levels and promoter methylation statuses in peripheral blood lymphocytes were measured in the evenings at five o'clock to avoid bias due to differences caused by circadian variations. All participants were otherwise physically and mentally healthy as assessed with the symptom check list SCL-90 R [19] and a brief physical examination. Several clinical 
scales were surveyed: the SWLS was employed to measure satisfaction with life [20], craving was assessed with a visual analogue scale, and the WHO-Assist V3.0 was performed for the assessment of subject involvement with alcohol, nicotine and illegal substances [21]. Furthermore, the severity of nicotine dependence was assessed with the Fagerström Test [22]. Finally, the severity of dependence score (SDS) developed by the WHO was assessed. The participants were sober at the time of enrolment into the study and had not taken vitamin supplements or other drugs before being enrolled in the study. The subjects showed no nutritional abnormalities, liver cirrhosis, renal or pancreatic dysfunction or psychiatric comorbidities.

The study characteristics of the participants such as medical history, socio-demographic data, time of drug or alcohol consumption, and the clinical scales were recorded using a semistructured interview in accordance with previous studies on alcoholism [23].

\section{Laboratory Analyses}

Fasting blood samples for RNA extraction were drawn at 17:00 h \pm 15 min in each case in Paxgene ${ }^{\mathrm{TM}}$ Blood RNA tubes (PreAnalytiX GmbH, Hombrechtikon, Switzerland) and were stored at $-80^{\circ} \mathrm{C} 2 \mathrm{~h}$ after collection according to the manufacturer's instructions. The total RNA was extracted from whole frozen blood in EDTA using Qiacube and the accordant protocol (QIAGEN GmbH, Hilden, Germany). Reverse transcription was performed using the Bio-Rad Laboratories' iScript cDNA Synthesis $\mathrm{Kit}^{\circledR}$ (BioRad Laboratories $\mathrm{GmbH}$ ) after measuring RNA quality and quantity using Nanodrop and Experion ${ }^{\mathrm{TM}}$ Automated Electrophoresis System (Bio-Rad Laboratories GmbH). Quantitative PCR was performed using SYBR Green $I^{\circledR}$ Master Mix buffer (Applied Biosystems, Germany), and the reactions were run on a Light Cycler $\left(\right.$ Roche $\left.^{\mathrm{TM}}\right)$ using a three-step standard protocol. The annealing temperature was optimized for the primer pair: $56^{\circ} \mathrm{C}$ for $\mathrm{CB} 1$ and $58^{\circ} \mathrm{C}$ for $\mathrm{CB} 2$. The PCR products were visualised on standard $2.0 \%$ agarose gels with ethidium bromide. $\beta$-Actin was used as an internal standard, and $\Delta \mathrm{CT}$ values were calculated from differences between $\beta$-actin and CB1 and CB2. All experiments were repeated at least three times, and the mean value was used for further analysis.

The following primer pairs were used: $\beta$-Actin-F: $5^{\prime}$-CTGGAACGGTGAAGGTGACA-3'; $\beta$-Actin-R: $5^{\prime}$-AAGGGACTTCCTGTAACAATGCA-3'; CB1-F: 5'-CAGAAGAGCATCATCCACACGTCTG-3'; CB1-R: 5'-ATGCTGTTATCCAGAGGCTGCGCAGTGC-3'; CB2-F: 5' ${ }^{\prime}$ TTTCCCACTGATCCCCAATG-3'; CB2-R: 5'-AGTTGATGAGGCACAGCATG-3'.

\section{Promoter Methylation Analysis of the CB1 Promoter}

As there were no significant differences in CB2 receptor expression in the pair-wise comparisons, only the $\mathrm{CB} 1$ promoter methylation status was examined. The analysis of $\mathrm{CB} 1$ receptor promoter DNA methylation was performed applying a methylation-sensitive digestion assay as previously described [24] followed by real-time PCR. First, genomic DNA was extracted from whole tissue with the QIAamp ${ }^{\circledR}$ DNA Blood and Tissue Kit (Qiagen Inc., Valencia, Calif., USA) according to the manufacturer's instructions. Then, $0.5-1 \mathrm{mg}$ of genomic DNA was digested overnight with a 10 -fold excess of $\mathrm{HpaII}$ or $\mathrm{MspI}$ endonuclease according to the manufacturer's protocol (New England Biolabs, Beverly, Mass., USA). MspI cuts independently from methylation sta- tus at 5'-CCGG-3' sites, whereas the cutting of HpaII depends on the respective DNA methylation status. In a $20-\mathrm{ml}$ assay, a total of $40 \mathrm{U}$ of each restriction enzyme was used for $16 \mathrm{~h}$ (with $20 \mathrm{U}$ used initially and another $20 \mathrm{U}$ after $4 \mathrm{~h}$ to complete DNA digestion).

To measure promoter methylation of the $\mathrm{CB} 1$ receptor gene, quantitative PCR of the CB1 promoter was performed using an SYBR Green I Master Mix buffer (Applied Biosystems, Darmstadt, Germany) with the following primers according to Frieling et al. [25]: CB1meth-F: 5'-TCCAAGAGTAGGGGTCATGTG-3'; CB1meth-R: 5'-CAGGGCCAAGAAGACTGAAC-3'.

To amplify the specific promoter region covering a CPG island, the PCR reaction was performed as follows: the PCR was performed with a final volume of $25 \mu$ l containing $1 \mu$ l of each primer, $1 \mu$ l of digested template DNA and $12.5 \mu$ l SYBR green ${ }^{\circledR}$ reagent (Biorad, Munich/Germany). The amplification was performed with initial denaturing at $97^{\circ} \mathrm{C}$ for $10 \mathrm{~min}$ followed by 50 cycles of denaturing at $95^{\circ} \mathrm{C}$ for $2 \mathrm{~min}$, annealing for $90 \mathrm{~s}$ at $61^{\circ} \mathrm{C}$ and extension for $1 \mathrm{~min}$ at $72^{\circ} \mathrm{C}$. The product was visualised with a $2 \%$ agarose gel. All experiments were repeated 2 times.

CT measurements were transformed using the following formula: promoter methylation $(\%)=\left[1 \_\left(2^{\mathrm{CT}} \_ \text {HpaII } / 2^{\mathrm{CT}} \_ \text {MspI }\right)\right] \times 100$ to calculate the percent methylation change.

\section{Statistical Analyses}

ANOVAs were used to test for marginal differences between groups. If significant differences were observed, post-hoc pairwise comparisons were performed.

Univariate analyses were applied to test for correlations between expression levels and promoter methylation considering sex, age, body mass index (BMI) and several clinical scales. A stepwise forward linear regression analysis was used to test for possible associations between different variables. A multivariate regression was used to test for possible associations between $\mathrm{CB} 1$ and $\mathrm{CB} 2$ mRNA expression levels and $\mathrm{CB} 1$ receptor promoter methylation.

All statistical tests were two-tailed with a significance level of $\alpha=0.05$. The data were analyzed using SPSS ${ }^{\mathrm{TM}}$ for Windows 18.0 (SPSS Inc., Chicago, Ill., USA).

\section{Results}

The demographic data and the results of the psychometric measures are reported in table 1 . There were no significantly relevant differences between the three groups with regards to age, sex distribution or BMI.

There was a significant difference in CB1 receptor expression levels between the three groups (ANOVA, d.f. = $2, \mathrm{~F}=71.3)$ and $\mathrm{CB} 2$ receptor expression only in the ANOVA analysis (ANOVA, d.f. $=2, \mathrm{~F}=4.2$; fig. 1). However, this significant difference in the ANOVA could not be confirmed by post-hoc pairwise comparison.

The differences between the three groups (THC consumers, cigarette smokers and nonsmokers) were also significant for $\mathrm{CB} 1$ promoter methylation status (ANO- 
Table 1. Results and demographic data (shown as the mean \pm SD)

\begin{tabular}{lccc}
\hline & $\begin{array}{l}\text { THC- } \\
\text { dependent }\end{array}$ & $\begin{array}{l}\text { Cigarette } \\
\text { smokers }\end{array}$ & $\begin{array}{l}\text { Non- } \\
\text { smokers }\end{array}$ \\
\hline Number & & & \\
$\quad$ Female & 8 & 6 & 6 \\
$\quad$ Male & 28 & 14 & 15 \\
Age, years & $31.6 \pm 7.1$ & $33.3 \pm 8.8$ & $30.9 \pm 8.7$ \\
BMI & $23.9 \pm 3.2$ & $25.6 \pm 2.9$ & $24.8 \pm 4.2$ \\
Cigarettes per day & $17.8 \pm 19.4$ & $13.75 \pm 6.0$ & 0 \\
Duration of cigarette smoking, & & & \\
$\quad$ & $13.2 \pm 6.3$ & $15.9 \pm 8.9$ & 0 \\
$\quad$ years & $8.58 \pm 7.54$ & $5.13 \pm 2.4$ & $5.6 \pm 3.3$ \\
Fagerström score & $3.7 \pm 3.2$ & $3.0 \pm 1.9$ & 0 \\
SWLS & $21.4 \pm 7.9$ & $29.2 \pm 4.1$ & $26.8 \pm 5.0$ \\
Craving for cannabis VAS, mm & $40.3 \pm 30.9$ & 0 & 0 \\
CB1 promoter methylation, \% & $89.0 \pm 4.2$ & $84.4 \pm 7.9$ & $62.5 \pm 13.4$ \\
$\Delta$ CT $\beta$-actin & & & \\
$\quad$ CB1 mRNA & $1.5 \pm 1.1$ & $5.7 \pm 1.5$ & $4.0 \pm 1.1$ \\
$\quad$ CB2 mRNA & $6.8 \pm 2.3$ & $7.6 \pm 2.3$ & $5.7 \pm 1.4$ \\
\hline
\end{tabular}

VA, d.f. $=2, \mathrm{~F}=66.9$; fig. 2). These results were confirmed with post-hoc pair-wise comparisons matching THC consumers with healthy controls. The differences in CB2 receptor expression levels failed to reach significance (data not shown), whereas CB1 receptor expression levels $(\mathrm{p}<0.001$ d.f. $=70 ; \mathrm{T}=-10.3 ; \mathrm{F}=3.3)$ and $\mathrm{CB} 1$ promoter methylation status $(\mathrm{p}<0.001$; d.f. $=74 ; \mathrm{T}=6.0 ; \mathrm{F}=$ 37.8) differed significantly between THC-dependent subjects and healthy controls even when grouped as cigarette smokers and nonsmokers: for CB1 receptor expression levels and healthy cigarette smokers, $\mathrm{p}<0.001$, d.f. $=50, \mathrm{~T}=2.7, \mathrm{~F}=-11.5$ and for $\mathrm{CB} 1$ promoter methylation status and cigarette smokers, $\mathrm{p}=0.006$, d.f. $=53$, $\mathrm{T}=2.9, \mathrm{~F}=6.3$. The differences for $\mathrm{CB} 1$ receptor expression levels $(\mathrm{p}<0.001$, d.f. $=50, \mathrm{~T}=-8.1, \mathrm{~F}=0.005)$ and for $\mathrm{CB} 1$ promoter methylation status $(\mathrm{p}<0.001$, d.f. $=55$, $\mathrm{T}=11.1, \mathrm{~F}=29.8$ ) were also significant compared to nonsmokers.

As the differences in CB2 receptor expression levels failed to reach significance in the post-hoc pair-wise comparisons between the three groups and between cannabis consumers and healthy controls, the promoter methylation status of the CB2 receptor was not assessed.

The mean promoter methylation (\%) was significantly negatively correlated to $\mathrm{CB} 1$ receptor mRNA expression considering the whole study population (Spearman's rho: $r=-0.37 ; p=0.002)$. As the value of the CB1 mRNA expression level is expressed as $\Delta \mathrm{CT} \beta$-actin, a higher rate

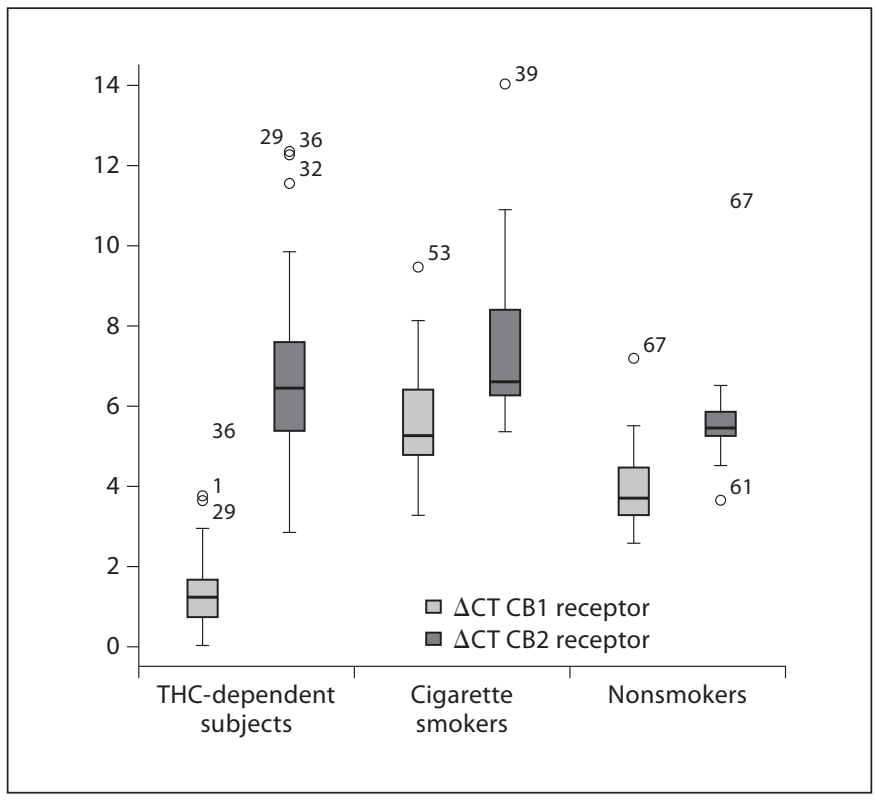

Fig. 1. $\mathrm{CB} 1$ and $\mathrm{CB} 2$ receptor expression levels comparing THCdependent subjects with cigarette smoking vs. nonsmoking controls. Changes in the expression $(\Delta \mathrm{CT} \beta$-actin) of the CB1 and CB2 receptor mRNA expression levels between the three groups. The box plots represent the raw data $\left({ }^{\circ}\right.$ represent cases with more than 1.5 box lengths from the upper or lower edge of the box, the box length is the interquartile range). The higher the $\Delta \mathrm{CT}$ value, the lower the expression. The differences are significant (see 'Results').

of promoter methylation is associated with a reduced amount of CB1 receptor mRNA (fig. 3).

Furthermore, CB1 receptor mRNA expression levels significantly correlated with the SWLS $(\mathrm{r}=0.486, \mathrm{p}<$ $0.001)$, the VAS of craving $(r=-0.655 ; p<0.001)$, the Fagerström test for nicotine dependence $(\mathrm{r}=-0.328, \mathrm{p}=$ 0.005 ) and two subscales of the WHO Assist: alcohol consumption $(\mathrm{r}=-0.283, \mathrm{p}=0.016)$ and cannabis consumption $(\mathrm{r}=-0.709, \mathrm{p}<0.001)$. In addition, CB1 promoter methylation status significantly correlated with the VAS of craving $(\mathrm{r}=0.478 ; \mathrm{p}<0.001)$ and three subscales of the WHO Assist: nicotine consumption $(r=0.508, p<0.001)$, alcohol consumption $(\mathrm{r}=0.418, \mathrm{p}<0.001)$ and cannabis consumption $(\mathrm{r}=0.518, \mathrm{p}<0.001)$. Sex, age and BMI did not influence the association of these variables.

Using a mixed general linear model to test for possible associations between expression and promoter methylation status and several clinical variables (BMI, sex, age, WHO nicotine, alcohol and cannabis subscales, SWLS and craving and the results from the Fagerström test), we 


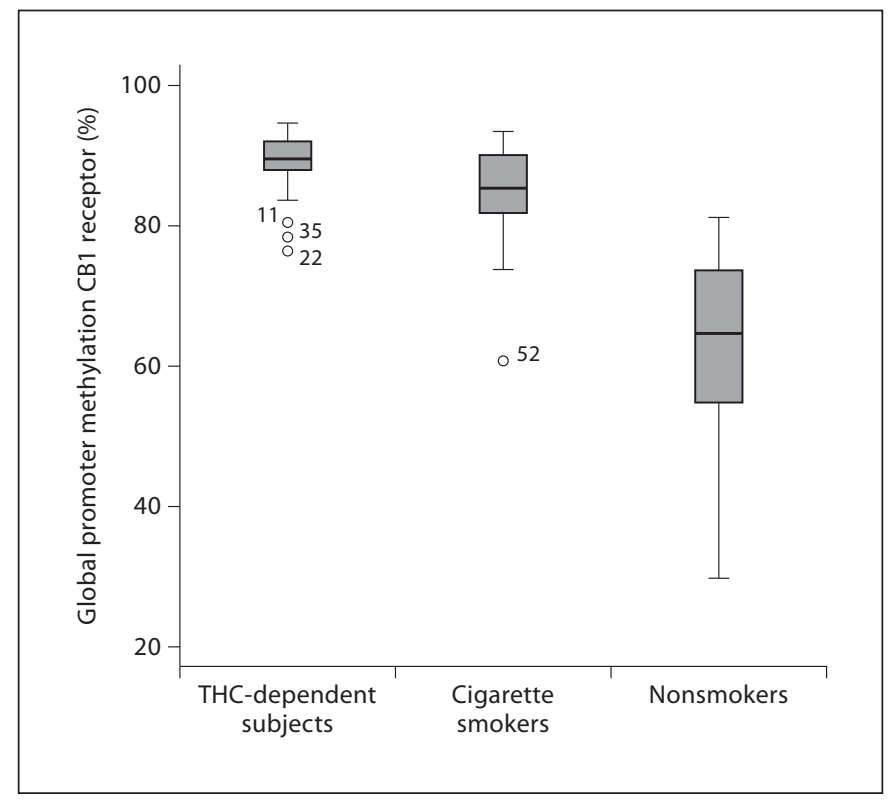

Fig. 2. $\mathrm{CB} 1$ receptor promoter methylation (\%) comparing THCdependent subjects with cigarette smoking vs. nonsmoking controls. The differences are significant (see 'Results').

found that the CB1 mRNA expression levels as the dependent variable was associated with the SWLS $(r=0.101$; $\mathrm{T}=2.8 ; \mathrm{p}=0.007)$, craving as measured with the VAS $(\mathrm{r}=-0.023 ; \mathrm{T}=-2.3 ; \mathrm{p}=0.023)$ and the WHO-Assist Subscale for Cannabis consumption $(\mathrm{r}=-0.068 ; \mathrm{T}=-2.4$; $\mathrm{p}=0.02$ ).

Using the mean promoter methylation of the CB1 receptor gene as the dependent variable, the promoter methylation status was significantly related only to the WHO Tobacco subscale $(\mathrm{r}=0.907 ; \mathrm{T}=4.3, \mathrm{p}<0.001)$ but showed a trend for BMI $(\mathrm{r}=0.683 ; \mathrm{T}=1.76, \mathrm{p}=0.083)$ and the WHO subscale for cannabis misuse $(\mathrm{r}=0.315$; $\mathrm{T}=$ $1.743 ; \mathrm{p}=0.087)$.

\section{Discussion}

CB1 mRNA expression levels and promoter methylation status were significantly higher in subjects with THC dependence compared to otherwise healthy cigarette smokers and nonsmokers. This finding agrees with results from animal studies showing a significant increase in striatum $\mathrm{CB} 1$ receptor mRNA levels with no changes in the hippocampus and cerebellum [26]. Studies from the past decade have demonstrated that $\mathrm{CB} 1$ receptors are

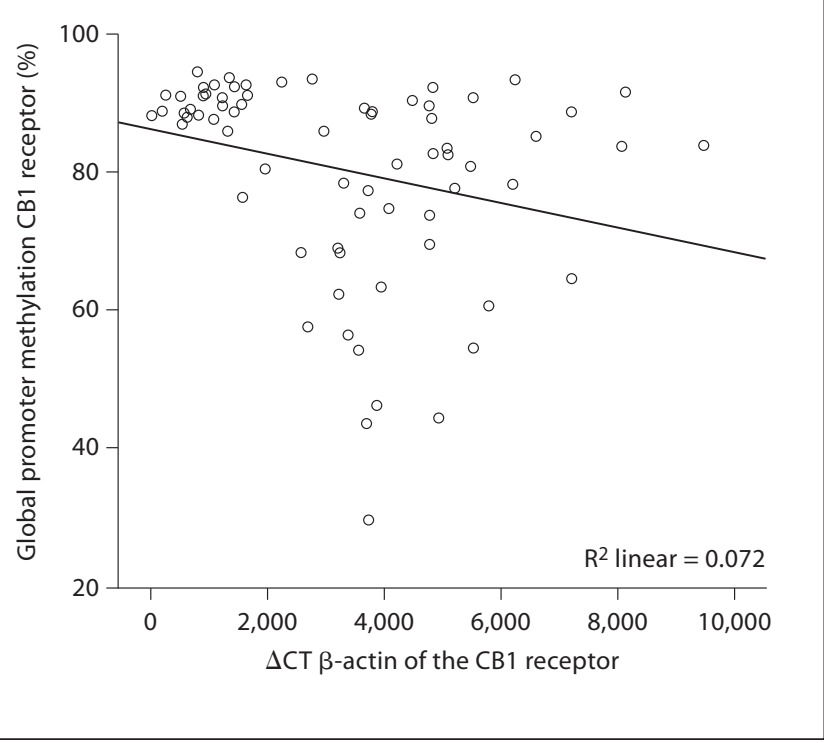

Fig. 3. CB1 promoter methylation (\%) negatively correlates with $\mathrm{CB} 1$ receptor mRNA expression levels. The results are significant in all three groups $(\mathrm{r}=-0.37 ; \mathrm{p}=0.002)$.

downregulated in extrapyramidal areas and are desensitized following chronic administration of either THC or synthetic cannabinoid agonists indicating that the primary action of delta-9-THC would be on the receptor protein itself rather than on the expression of CB1 receptor gene [26].

The mean promoter methylation was significantly negatively correlated with CB1 receptor mRNA expression, indicating that the higher the promoter methylation, the lower the amount of $\mathrm{CB} 1$ receptor mRNA. In general, DNA methylation is one of the most important epigenetic modifications. DNA methylation provides a stable and heritable component of epigenetic regulation and moderates gene-environment interactions [15]. DNA methylation primarily occurs on the cytosine residues of CpG dinucleotides, which are mainly aggregated into socalled CpG islands at the regulatory sites of gene promoter regions. The mean promoter methylation of the CPG Island within the promoter of the CB1 receptor gene was assessed. The amount of DNA methylation in a gene-control region generally inversely correlates with gene activation $[27,28]$; gene activation is demonstrated as a higher level of mRNA expression as shown in this study. Methylation-sensitive transcription factors and methyl-binding proteins are transcriptional complex proteins that 
bind to specific methyl groups on CpG dinucleotides in association with gene silencing [29]. Thus, DNA methylation and expression of the CB1 receptor mRNA appear to play an important role in the development of THC dependence. Nevertheless, the application of exogenous cannabinoids in different doses as observed in THC dependence is nonphysiological and does not appropriately imitate the effects of endocannabinoids that are released in response to special inputs. Endocannabinoids normally affect the CB1 receptors that regulate the release of inhibitory and excitatory neurotransmitters and thereby influence neuronal plasticity [6]. Taking this line of thought further, the physiological function of $\mathrm{CB} 1$ receptors might be severely altered in THC dependence leading to a disruption in the subtle balance of neural plasticity and contributing to the development of psychiatric diseases such as schizophrenia or depression that are observed more frequently in THC-dependent subjects [4]. Furthermore, experiments in rodents have shown that the withdrawal syndrome is also mediated by CB1 receptors [6].

The present study assessed the changes in CB1 receptor mRNA expression levels and promoter methylation status relative to the results from the SWLS, craving, the severity of nicotine dependence and severity of alcohol and cannabis consumption that might possibly be related to brain status. Sex, age and BMI did not influence the association of these variables, although global leukocyte DNA methylation differs by gender and race/ethnicity but not with age, cigarette smoking and body weight [30]. To date, no causal relationship between leukocyte DNA methylation, RNA expression and these clinical variables can be established apart from the hypothesis that the differences described in this study might serve as surrogate markers for brain status that is difficult to assess in clinical studies.

The results of the mixed general linear model demonstrated an association between CB1 mRNA expression levels and a lower score on the SWLS and increased craving and cannabis consumption. Using the mean promoter methylation of the $\mathrm{CB} 1$ receptor gene as the dependent variable, the promoter methylation status was significantly related only to the results of the WHO-Assist Tobacco Subscale. Human laboratory studies have shown that THC acting on the CB1 receptor is the primary component for the reinforcing properties of marijuana [31]. However, the precise role of the CB1 receptor in humans for drug reinforcement has not yet been specified. The present study showed a higher expression of CB1 receptor subtype in THC-dependent subjects in association with a lower satisfaction of life and craving. It appears reasonable to assume that a high craving might be followed by a lower satisfaction with life accompanied by higher CB1 receptor mRNA expression levels that are measurable in peripheral blood leukocytes. The association between craving and CB1 receptor mRNA expression levels has been described previously in several different animal addiction models [6]. In humans, CB1 antagonists such as Rimonabant have been found to have significant benefits in smoking cessation with a nearly two-fold increase in nicotine abstinence after 10 weeks compared to placebo [32]. Tobacco and cannabis misuse appears to be associated as reported in a study by Monshouwer et al. [33] that examined a large cohort of subjects exposed to prenatal tobacco smoking. This examination agrees with the results of the presented study showing a high prevalence of tobacco smoking in THCconsuming subjects. Another potential role for endocannabinoids is the reinforcing effect of alcohol. A CB1 receptor blockade decreases alcohol consumption and cravings, whereas its activation increases the amount of alcohol intake [34] possibly explaining the association between elevated CB1 receptor expression and severity of alcohol and nicotine intake as measured by the Fagerström Scale and the WHO Assist subscales for Nicotine and Alcohol and THC.

In general, the application of CB1 blockers has also been discussed in a variety of 'craving' disorders such as cocaine or heroin abuse [35]. It has been assumed that CB1 antagonists affect the endocannabinoid system through the antagonism of $\mathrm{CB} 1$ receptors targeting the midbrain dopamine neurones that again regulate drug reward processes moderating craving [36].

Nevertheless, there are considerable limitations intrinsic to these types of naturalistic studies on clinical samples.

The research on the changes in epigenetic phenomena and receptor expression within the brain is not always easy to obtain; therefore, easily accessible and mainly peripheral markers are required. $\mathrm{CB} 1$ and $\mathrm{CB} 2$ receptor expression may be possible candidates that can further elucidate the mechanisms of THC dependence, because exogenous and endogenous cannabinoids are administered systemically and exert their influence throughout the whole body. Therefore, it can be hypothesized that the changes found in this study might to some extent reflect brain status.

It has been shown that the adaptation of $\mathrm{CB} 1$ receptor expression to chronic THC administration is regionally widespread and accounts for the different effects of THC 
on human beings [37]. Therefore, the results from this study might only represent peripheral changes relative to THC and nicotine consumption that do not necessarily reflect brain status; however, research on animals has found similar results of a CB1 receptor mRNA up-regulation in specific brain areas following chronic THC administration [26].

In conclusion, the present study shows that the expression levels of the $\mathrm{CB} 1$ receptor gene and its promoter methylation in peripheral blood lymphocytes might be easily accessible candidates as biological markers for future research into the mechanisms of THC action and dependence and possibly also other types of addiction. As the peripheral expression of $\mathrm{CB} 1$ receptor was significantly altered with regards to THC dependence or smoking status, the peripherally expressed promoter methylation was assessed as previously performed in studies on alcohol dependence and depression [38, 39]. Nevertheless, it appears probable that the methylation status varies with the respective brain region.

In summary, the results of this study propose an association between THC dependence, CB1 receptor expression levels and promoter methylation status, cravings and satisfaction with life, warranting further studies into the exact mechanisms of these relationships.

\section{References}

1 Cooper ZD, Haney M: Cannabis reinforcement and dependence: role of the cannabinoid cb1 receptor. Addict Biol 2008;13:188195.

2 Noack R, Hofler M, Lueken U: Cannabis use patterns and their association with dsm-iv cannabis dependence and gender. Eur Addict Res 2011;17:321-328.

3 Compton WM, Grant BF, Colliver JD, Glantz MD, Stinson FS: Prevalence of marijuana use disorders in the United States: 1991-1992 and 2001-2002. JAMA 2004;291:2114-2121.

4 Shapiro GK, Buckley-Hunter L: What every adolescent needs to know: cannabis can cause psychosis. J Psychosom Res 2010;69: 533-539.

5 Agosti V, Nunes E, Levin F: Rates of psychiatric comorbidity among US residents with lifetime cannabis dependence. Am J Drug Alcohol Abuse 2002;28:643-652.

6 Iversen L: Cannabis and the brain. Brain 2003; 126:1252-1270.

7 Bab I, Zimmer A, Melamed E: Cannabinoids and the skeleton: from marijuana to reversal of bone loss. Ann Med 2009;41:560-567.

8 Howlett AC: The cannabinoid receptors. Prostaglandins Other Lipid Mediat 2002; 68-69:619-631.

9 Howlett AC, Breivogel CS, Childers SR, Deadwyler SA, Hampson RE, Porrino LJ: Cannabinoid physiology and pharmacology: 30 years of progress. Neuropharmacology 2004;47(suppl 1):345-358.

10 Green B, Kavanagh D, Young R: Being stoned: a review of self-reported cannabis effects. Drug Alcohol Rev 2003;22:453-460.

11 Hall W, Degenhardt L: Adverse health effects of non-medical cannabis use. Lancet 2009; 374:1383-1391.

12 Agrawal A, Lynskey MT: The genetic epidemiology of cannabis use, abuse and dependence. Addiction 2006;101:801-812.
13 Agrawal A, Lynskey MT: Candidate genes for cannabis use disorders: findings, challenges and directions. Addiction 2009;104:518532.

14 McClung CA, Nestler EJ: Neuroplasticity mediated by altered gene expression. Neuropsychopharmacology 2008;33:3-17.

15 Rodenhiser D, Mann M: Epigenetics and human disease: translating basic biology into clinical applications. CMAJ 2006;174:341348.

16 Parmentier-Batteur S, Jin K, Xie L, Mao XO, Greenberg DA: DNA microarray analysis of cannabinoid signaling in mouse brain in vivo. Mol Pharmacol 2002;62:828-835.

17 Henquet C, Di Forti M, Morrison P, Kuepper R, Murray RM: Gene-environment interplay between cannabis and psychosis. Schizophr Bull 2008;34:1111-1121.

18 Ehrlich S, Walton E, Roffman JL, Weiss D, Puls I, Doehler N, Burghardt R, Lehmkuhl $\mathrm{U}$, Hillemacher T, Muschler M, Frieling $\mathrm{H}$ : Smoking, but not malnutrition, influences promoter-specific DNA methylation of the proopiomelanocortin gene in patients with and without anorexia nervosa. Can J Psychiatry 2012;57:168-176.

19 Derogatis LR, Rickels K, Rock AF: The Scl-90 and the MMPI: a step in the validation of a new self-report scale. Br J Psychiatry 1976; 128:280-289.

20 Diener E, Emmons RA, Larsen RJ, Griffin S: The satisfaction with life scale. J Pers Assess 1985;49:71-75.

21 Group WAW: The alcohol, smoking and substance involvement screening test (Assist): Development, reliability and feasibility. Addiction 2002;97:1183-1194.

22 Fagerstrom KO: Measuring degree of physical dependence to tobacco smoking with reference to individualization of treatment. Addict Behav 1978;3:235-241.
23 Bleich S, Carl M, Bayerlein K, Reulbach U, Biermann T, Hillemacher T, Bonsch D, Kornhuber J: Evidence of increased homocysteine levels in alcoholism: the Franconian alcoholism research studies (FARS). Alcohol Clin Exp Res 2005;29:334-336.

24 Bleich S, Lenz B, Ziegenbein M, Beutler S, Frieling H, Kornhuber J, Bonsch D: Epigenetic DNA hypermethylation of the HERP gene promoter induces down-regulation of its mRNA expression in patients with alcohol dependence. Alcohol Clin Exp Res 2006; 30:587-591.

25 Frieling $\mathrm{H}$, Albrecht $\mathrm{H}$, Jedtberg S, Gozner A, Lenz B, Wilhelm J, Hillemacher T, de Zwaan M, Kornhuber J, Bleich S: Elevated cannabinoid 1 receptor mRNA is linked to eating disorder related behavior and attitudes in females with eating disorders. Psychoneuroendocrinology 2009;34:620-624.

26 Romero J, Garcia-Palomero E, Castro JG, Garcia-Gil L, Ramos JA, Fernandez-Ruiz JJ: Effects of chronic exposure to delta9-tetrahydrocannabinol on cannabinoid receptor binding and $\mathrm{mRNA}$ levels in several rat brain regions. Brain Res Mol Brain Res 1997;46: 100-108.

27 Cross SH, Bird AP: CPG islands and genes. Curr Opin Genet Dev 1995;5:309-314.

28 Razin A, Riggs AD: DNA methylation and gene function. Science 1980;210:604-610.

29 Callinan PA, Feinberg AP: The emerging science of epigenomics. Hum Mol Genet 2006; 15:R95-R101.

30 Zhang FF, Cardarelli R, Carroll J, Fulda KG, Kaur M, Gonzalez K, Vishwanatha JK, Santella RM, Morabia A: Significant differences in global genomic DNA methylation by gender and race/ethnicity in peripheral blood. Epigenetics 2011;6:623-629. 
31 Haney M, Comer SD, Ward AS, Foltin RW, Fischman MW: Factors influencing marijuana self-administration by humans. Behav Pharmacol 1997;8:101-112.

32 Cleland JG, Ghosh J, Freemantle N, Kaye GC, Nasir M, Clark AL, Coletta AP: Clinical trials update and cumulative meta-analyses from the American College of Cardiology: watch, scd-heft, dinamit, casino, inspire, stratus-us, rio-lipids and cardiac resynchronisation therapy in heart failure. Eur J Heart Fail 2004;6:501-508.
33 Monshouwer K, Huizink AC, Harakeh Z, Raaijmakers QA, Reijneveld SA, Oldehinkel AJ, Verhulst FC, Vollebergh WA: Prenatal smoking exposure and the risk of behavioral problems and substance use in adolescence: the trails study. Eur Addict Res 2011;17:342350.

34 Mechoulam R, Parker L: Cannabis and alcohol - a close friendship. Trends Pharmacol Sci 2003;24:266-268.

35 Mackie K: Cannabinoid receptors as therapeutic targets. Annu Rev Pharmacol Toxicol 2006;46:101-122.

36 Lupica CR, Riegel AC: Endocannabinoid release from midbrain dopamine neurons: a potential substrate for cannabinoid receptor antagonist treatment of addiction. Neuropharmacology 2005;48:1105-1116.
37 Sim-Selley LJ: Regulation of cannabinoid cb1 receptors in the central nervous system by chronic cannabinoids. Crit Rev Neurobiol 2003;15:91-119.

38 Bayerlein K, Kraus T, Leinonen I, Pilniok D, Rotter A, Hofner B, Schwitulla J, Sperling W, Kornhuber J, Biermann T: Orexin A expression and promoter methylation in patients with alcohol dependence comparing acute and protracted withdrawal. Alcohol 2011;45: 541-547.

39 Lawrence AJ: Regulation of alcohol-seeking by orexin (hypocretin) neurons. Brain Res 2010;1314:124-129. 